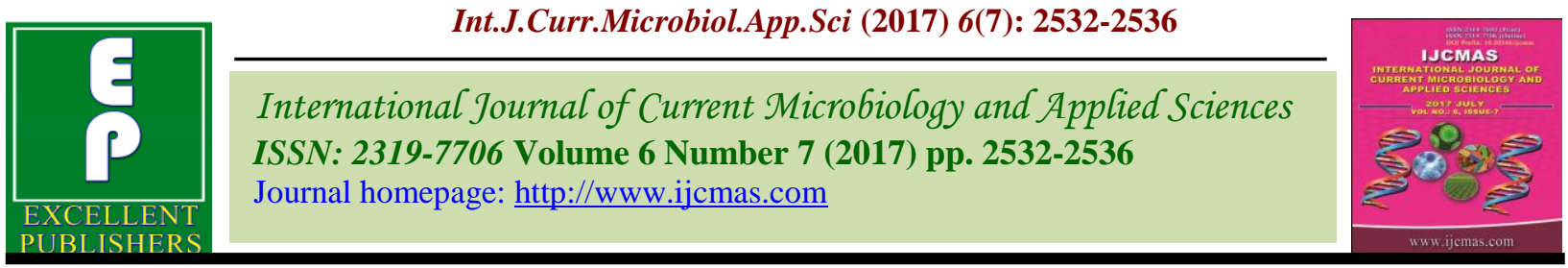

Original Research Article

https://doi.org/10.20546/ijcmas.2017.607.358

\title{
Screening of Maize Genotypes under Rainfed Condition of Madhya Pradesh, India
}

\author{
Neelam Bisen $^{1}$, R.P. Sahu ${ }^{1}$, C.P. Rahangdale ${ }^{1}$ and K. Hemalatha ${ }^{2}$ \\ ${ }^{1}$ Jawaharlal Nehru Krishi Vishwa Vidyalaya, Jabalpur (481001), M.P. India \\ ${ }^{2}$ Institute of Agriculture Sciences, Banaras Hindu University, Varanasi (221005), U.P. India \\ *Corresponding author
}

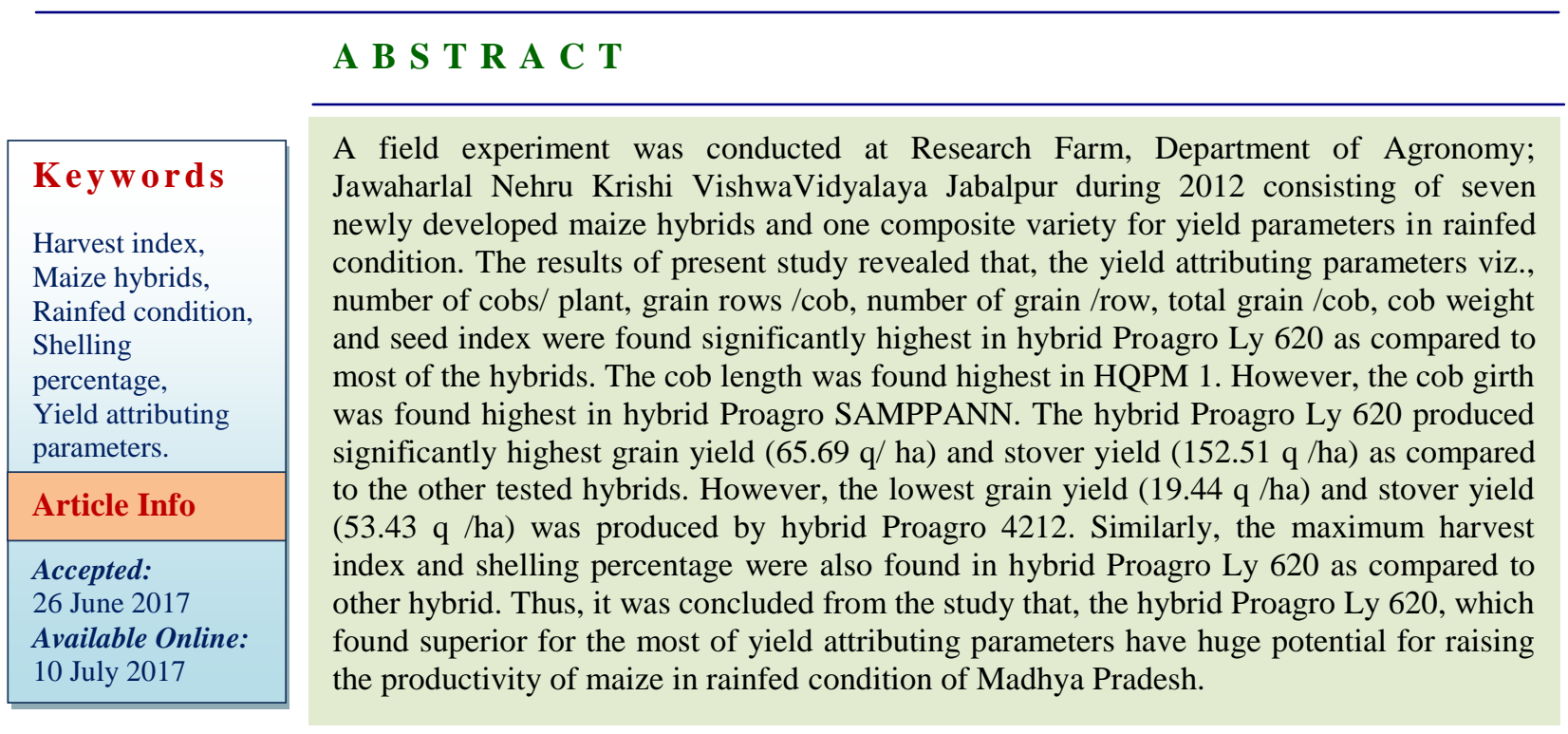

\section{Introduction}

Maize (Zea mays L.; 2n=20) belongs to family Poaceae and grown as multipurpose crop in the world. It is well adapted to subtropical, tropical and temperate regions of the world. Maize plays an important role in Indian economy. It is third most important cereal crop after rice and wheat and contributes $8 \%$ in national food basket and has the highest growth rate among the cereals. It contribute more than 400 billion rupees to the agriculture GDP at current prices apart from generating employment to over 1000 million man days at the farm and downstream agricultural and industrial sectors. Maize provides the nutritional security as it contains $72 \%$ starch, $10 \%$ protein, $4.8 \%$ oil, $8.5 \%$ fiber, $3 \%$ sugar and $1 \%$ ash.

At present the yield potential of our existing varieties is deteriorating day by day, so the selection of good varieties with high potential and wide range of adoptability is highly essential and tolerance to biotic and abiotic stresses. The likely cause for high yield in modern hybrids has been more cob bearing plants unit land area $^{-1}$ without reduction in grain $\mathrm{cob}^{-1}$. The adoption of high yielding suitable hybrids not only improves the grain 
yield and its quality but also leads to higher income hectare ${ }^{-1}$ as compared to conventional varieties of maize. Nazir et al., (2006) stated that maize hybrids usually have high yield potential than open pollinated varieties due to hybrids vigour. Olaoye (2009) emphasized the need to evaluate maize varieties in various agro-ecological zones for their adaptation, yield potential and disease reactions so as to release suitable varieties for cultivation on farmers' fields. It is, therefore, imperative to understand the relationship among yield testing locations for better adaptation of germplasm to different production environments. So, keeping above point in view, the present study conducted to compare the production potential of different newly developed maize hybrids under Kymore plateau and Satpura hill zone of Madhya Pradesh.

\section{Materials and Methods}

The present experiment was laid out at Research Farm, JNKVV Jabalpur (M.P.) during kharif, 2012. The experimentation site lies between $23^{0} 91^{\prime}$ North Latitude, $79^{\circ} 58^{\prime}$ East Longitude with an altitude of 411.78 meters above the mean sea level, which comes under the agro-climatic zone classified as Kymore Plateau and Satpura Hill Zone of Madhya Pradesh, India. The soil of experimental field was clayey in texture and neutral in reaction (7.3) with neutral electrical conductivity $(0.31 \mathrm{ds} / \mathrm{m})$ and medium in available $\mathrm{N}$ (395 kg / ha), P (17.85 kg /ha) and organic carbon $(0.64 \%)$ and high in available $\mathrm{K}$ (301 $\mathrm{kg} / \mathrm{ha})$. The 7 newly developed maize hybrids viz., Proagro-Ly 620, Proagro SAMPPANN, Proagro 4644, Proagro 4640, Proagro 4558, Proagro 4794, Proagro 4212 and one composite HQPM 1 were testes in randomized complete block design (RCBD) with 3 replications, having a net plot size of $4.0 \mathrm{~m} \times 2.4 \mathrm{~m}$. The sowing of seeds were done with the help of dibbler using seed rate of $18 \mathrm{~kg} /$ ha with plant to plant distance of $25 \mathrm{~cm}$ and row to row distance 60cm sown on 7 July 2012,. Fertilizer was applied @ $120 \mathrm{~kg} \mathrm{~N}, 60 \mathrm{~kg} \mathrm{P}$ and $40 \mathrm{~kg} \mathrm{~K} / \mathrm{ha}$. The recommended plant plant population $/ \mathrm{m}^{2}$ maintained in each net plot.

The number of cobs/ plant was counted from 5 already tagged plants in each plot. The cob length and girth of five cobs was measured from meter scale and digital vernier calipers respectively. The grain rows /cob, grains /row and grains/ cob were counted manually. For recording seed index, representative seed sample were taken from the produce of each plot and then 100 seeds were counted manually and finally, their weight was taken accurately with the help of electronic balance. The shelling percentage was worked out for each plot by using the following formula:

Shelling percentage $=\left(\right.$ Grain weight $\operatorname{cob}^{-1} /$ Weight of whole cob) x 100 .

The grain yield of each plot was recorded after shelling the cobs seed yield/plot was converted into seed yield per hectare by multiplying the conversion factor. The stover yield obtain from the total of bundle weight, husk weight and the head remaining after selling of maize of respective plots. The harvest index was calculated for each plot by the formula given by Nichiporvich (1987).

Harvest index $=$ (Economical yield / Biological yield) x 100

Data recorded on various observations were tabulated and subjected to their statistical analysis by using techniques of the analysis of variance by Panse and Sukhatme (1967).

\section{Results and Discussion}

The different maize genotypes showed the significant variations for yield and yield attributing parameters (Table 1). 
Table.1 Yield and yield attributing parameters of different maize genotype

\begin{tabular}{|c|c|c|c|c|c|c|c|c|c|c|c|c|}
\hline Treatments & $\begin{array}{l}\text { Cobs } \\
\text { /Plant }\end{array}$ & $\begin{array}{l}\text { Grain } \\
\text { rows } \\
\text { /Cob }\end{array}$ & $\begin{array}{l}\text { Grains } \\
\text { /Row }\end{array}$ & $\begin{array}{l}\text { Grains } \\
\text { /Cob }\end{array}$ & $\begin{array}{l}\text { Cob } \\
\text { length } \\
\text { (cm) }\end{array}$ & $\begin{array}{l}\text { Cob } \\
\text { girth } \\
\text { (cm) }\end{array}$ & $\begin{array}{l}\text { Cob } \\
\text { weight } \\
\text { (g) }\end{array}$ & $\begin{array}{l}\text { Seed } \\
\text { index } \\
(\mathrm{g})\end{array}$ & $\begin{array}{l}\text { Grain } \\
\text { yield } \\
\text { (q/ha) }\end{array}$ & $\begin{array}{l}\text { Stover } \\
\text { yield } \\
\text { (q/ha) }\end{array}$ & $\begin{array}{l}\text { Shelling } \\
\%\end{array}$ & $\begin{array}{l}\text { Harvest } \\
\text { index } \\
(\%)\end{array}$ \\
\hline Proagro-Ly 620 & 1.20 & 13.33 & 28.53 & 380.73 & 15.63 & 4.17 & 99.86 & 33.29 & 65.69 & 152.51 & 81.75 & 30.13 \\
\hline Proagro SAMPPANN & 1.13 & 12.20 & 25.88 & 315.73 & 13.59 & 4.51 & 94.58 & 32.89 & 46.53 & 110.43 & 78.09 & 29.64 \\
\hline Proagro 4644 & 0.87 & 11.43 & 23.90 & 273.33 & 15.46 & 4.09 & 80.23 & 30.14 & 25.29 & 83.51 & 76.51 & 23.13 \\
\hline Proagro 4640 & 0.93 & 11.60 & 25.11 & 291.22 & 13.09 & 4.46 & 93.71 & 32.51 & 41.66 & 104.43 & 78.01 & 28.44 \\
\hline Proagro 4558 & 1.20 & 12.60 & 26.27 & 330.91 & 13.73 & 4.24 & 96.46 & 33.16 & 53.82 & 135.55 & 78.08 & 28.38 \\
\hline Proagro 4794 & 0.93 & 12.13 & 24.13 & 292.77 & 16.47 & 4.20 & 93.02 & 31.39 & 29.43 & 94.05 & 75.12 & 23.78 \\
\hline Proagro 4212 & 0.80 & 10.60 & 22.13 & 234.81 & 13.53 & 3.59 & 48.51 & 27.93 & 19.44 & 53.43 & 70.47 & 26.54 \\
\hline HQPM 1 & 1.00 & 11.53 & 25.01 & 288.41 & 16.97 & 4.01 & 93.67 & 30.54 & 32.93 & 101.67 & 76.25 & 24.43 \\
\hline SEm \pm & 0.08 & 0.18 & 0.79 & 3.96 & 0.54 & 0.03 & 1.61 & 0.59 & 2.29 & 2.73 & 1.03 & 0.80 \\
\hline $\mathrm{CD}(\mathrm{P}=0.05)$ & 0.24 & 0.55 & 2.39 & 11.98 & 1.62 & 0.10 & 4.87 & 1.77 & 6.92 & 8.26 & 3.11 & 2.41 \\
\hline
\end{tabular}


The number of cobs/ plant (1.20), grain rows /cob (13.33), number of grain/ row (28.53), total grain/ cob (380.73), cob weight (99.86 g) and seed index $(33.29 \mathrm{~g})$ were found significantly higher in hybrid Proagro Ly 620 as compared to most of the hybrids. However, the number of cobs /plant (0.80), grain rows/ cob (10.60), number of grain /row (22.13), total grain/ cob (234.81), cob weight (27.93 g) and seed index (27.93 g) were found lowest in hybrid Proagro 4212. The cob length (16.47 $\mathrm{cm}$ ) was found maximum in genotype HQPM 1. However, the cob girth was found highest (4.51) in hybrid Proagro SAMPPANN as compared to others hybrid tested. Both cob length $(13.53 \mathrm{~cm})$ and cob girth $(3.39 \mathrm{~cm})$ was found lowest in hybrid Proagro 4212. The variation in cob bearing abilities and seed size among the hybrids may be due to variability in the variable inheritance. These results are in agreement with findings of Tahir et al., (2008), Malik et al., (2009), Singh and Chauhan (2010).

It is clear from the results that, the genotypic effect on grain and stover yield was found significant (Table 1). The hybrid Proagro Ly 620 produced significantly highest grain yield (65.69 q/ ha) and stover yield (152.51 q /ha) than the other tested hybrids. However, the lowest grain yield (19.44 q /ha) and stover yield (53.43 q/ ha) was produced by hybrid Proagro 4212. The grain yield per hectare is the final expression of physiological and metabolic activities of a plant and a product of cumulative action of all factors contributing to batter growth viz. number of cobs/ plant, grains /cob and seed index. The yield is a complex trait and exhibits continuous variation, such continuous variation being generally attributed to polygenic control. The yield is governed not only by polygene but also highly influenced by environmental fluctuations. These results were collaborated with the findings of Tahir et al., (2008) and Malik et al., (2010). The harvest index (30.13\%) and shelling percentage $(81.75 \%)$ were also found maximum in hybrid Proagro Ly 620 as compared to other tested genotypes. However, the minimum shelling percentage was found in Proagro 4212 (70.47 \%) and harvest index was found in Proagro 4644 i.e., $23.13 \%$. The similar result trends were also reported by Tahir et al., (2008), Malik et al., (2009), Singh and Chauhan (2010) and Sobhana et al., (2012).

From the result it was concluded that, the hybrid Proagro Ly 620, found superior for the most of yield attributing parameters. It has huge potential for raising the productivity of maize in rainfed condition of Madhya Pradesh.

\section{References}

Malik Haq Nawaz, Iffat Ara, Muhammad Naeem, Mozammil Hussain, M. Hanif Munawwar and M. Yousaf. 2009. Comparison of open pollinated varities and newly developed hybrids for yield and yield contributing traits in maize. Pak. J. Agri. Res., 23(1-2): 37-41.

Nazir, H., F. Khan, E. Ahamd, A.A. Khan and Q. Zaman. 2006. Evaluation of corn hybrids under agro-ecological conditions of D.I. Khan. Sarhad J. Agri., 22: 633-636.

Nichiporvich, A.A. 1987. Aims of reseach on the photosynthesis of plant as a factor of production (In.) photosynthesis of productive system programme for science translation, Jeruselem, Israel. pp 3-36.

Olaoye, G. 2009. Evaluation of new generations of maize streak virus (MSV) resistant varieties for grain yield, agronomic potential and adaptation to southern guinea savanna ecology of Nigeria. J. Trop. Agric. Food, Environ. Ext., 8(2): 104-109. 
Panse, V.G. and Sukhatme, P.V. 1967. Statistical methods of agricultural workers. ICAR publication, New Delhi.

Shobhana, V., Ashok Kumar, Idnani, L.K. Singh, Inshwer and Shivadhar. 2012. Plant population and nutrient requirement for baby corn hybrids (Zea mays). Indian J. Agron., 57(3): 294-296.

Singh, Indrakumar N. and Chauhan, J.S. 2010. Evaluation of Quantitative
Physiological Traits of Some Hybrid Maize. World J. Agri. Sci., 6(3): 297300.

Tahir, M., Tanveer Asif, Ali Asghar, Abbas Muhammad and Wasaya Allah. 2008. Comparative yield performance of different maize (Zea Mays L.) hybrids under local conditions of Faisalabad. Pakistan. Pak. J. Life Sci., 6(2): 118120.

\section{How to cite this article:}

Neelam Bisen, R.P. Sahu, C.P. Rahangdale and Hemalatha, K. 2017. Screening of Maize Genotypes under Rainfed Condition of Madhya Pradesh. Int.J.Curr.Microbiol.App.Sci. 6(7): 2532-2536. doi: https://doi.org/10.20546/ijcmas.2017.607.358 